\title{
Effect of Planting Pattern and Weed Management Practices on Weeds and Yields of Field Pea and Baby Corn in Field Pea + Baby Corn Intercropping System
}

\author{
Moirangthem Thoithoi Devi* and V. K. Singh
}

Department of Agronomy, G.B. Pant University of Agriculture and Technology, Pantnagar, U.S. Nagar-263145, India

*Corresponding author

\section{A B S T R A C T}

\section{Keywords}

Baby corn, Field pea equivalent yield, Field pea, Planting pattern

\section{Article Info}

Accepted:

12 November 2019

Available Online:

10 December 2019
A field experiment was conducted during two consecutive seasons of rabi 2011-13 at Crop Research Centre of G.B. Pant University of Agriculture and Technology, Pantnagar to find out the effect of planting pattern and weed management practices on weed growth and yields of field pea and baby corn in field pea (Pant P-13) + baby corn(Surya) intercropping system. The experiment was laid out in split plot design keeping four planting patterns as main plot and four weed management practices as sub plot with three replications. Paired planting of maize $(30 / 60 \mathrm{~cm})+$ field pea $(2: 2)$ and planting of maize + field pea (1:1) had lower total weed density and weed dry weight and higher weed control efficiency than sole planting of field pea or baby corn. Sole planting of field pea recorded significantly higher grain (2264 and $\left.1434 \mathrm{~kg} \mathrm{ha}^{-1}\right)$ and straw yields(3263 and $\left.2540 \mathrm{~kg} \mathrm{ha}^{-1}\right)$ during 2011-12 and 2012-2013than yield obtained as a component crop in paired planting of maize $(30 / 60 \mathrm{~cm})$ + field pea (2:2) and planting of maize + field pea (1:1).Baby corn yield was similar in sole, paired (2:2) and 1:1planting but significantly higher stover yield of baby corn(3576 $\mathrm{kg} \mathrm{ha}^{-1}$ and $3533 \mathrm{~kg} \mathrm{ha}^{-1}$,during 2011-12 and 2012-2013 respectively)was obtained from sole crop than other planting methods during both the years. Both the intercropping systems had significantly higher field pea equivalent yield than sole crop of either field pea or baby corn. The lowest total weed density $\left(66.5\right.$ and $67.3 \mathrm{plants} / \mathrm{m}^{2}$, during 2011-12 and 2012-2013 respectively) and weed dry weight (99.4 and $99.7 \mathrm{~g} \mathrm{~m}^{-2}$,during 2011-12 and 2012-2013 respectively) was recorded in hand weeding at 90 days after sowing which was followed by pre-emergence application of pendimethalin $1 \mathrm{~kg} \mathrm{ha}^{-1}$, post-emergence application of imazethapyr $50 \mathrm{~g} \mathrm{ha}^{-1}$ and weedy check. Significantly higher weed control efficiency was recorded from one hand weeding (56.07 and 56.52\%)and pre-emergence application of pendimethalin $1 \mathrm{~kg} \mathrm{ha}^{-1}$ (55.37and 56.49\%) during 2011-2012and 2012-2013 than post emergence application of imazethapyr $50 \mathrm{~g} \mathrm{ha}^{-1}(30.08$ and $30.36 \%$ respectively). Hand weeding, pre-emergence application of pendimethalin $1 \mathrm{~kg} \mathrm{ha}^{-1}$ and post-emergence application of imazethapyr $50 \mathrm{~g} \mathrm{ha}^{-1}$ (30 days after sowing) improved all the growth and yield parameters of field pea and baby corn than weedy check. Hand weeding, preemergence application of pendimethalin $1 \mathrm{~kg} \mathrm{ha}^{-1}$ and post-emergence application of imazethapyr $50 \mathrm{~g} \mathrm{ha}^{-1}$ had significantly higher field pea equivalent yield than weedy check. 


\section{Introduction}

Intercropping of cereals with pulses is an age old practice. Pulses can do wonder when intercropped with widely spaced crops like maize, sorghum, pearl millet, cotton and sugarcane particularly in Northern India (Punjab, Haryana, Uttar Pradesh, Rajasthan, Bihar). There are evidences that intercropping of short growing grain legumes with tall cereals give higher productivity than corresponding sole crops (Rao and Willey, 1983). Field pea (Pisum sativum), one of the important pulse crop of winter season has great potential to contribute to the pulse basket in India. Maize, the queen of cereals, is cultivated worldwide round the year.

During the recent past, it has been used as vegetable where unfertilized cob is used for cooking purpose, popularly known as baby corn (Zea mays L.) (Barod et al., 2012) Introduction of baby corn during off season (winter months), because of its photo and thermo insensitiveness will promote nutritive dish of the people and also fetch additional income to farming community. Normally baby corn is planted in wider rows and a considerable portion of the incident solar radiation remains unintercepted due to poor canopy development because of its slow growth during winter season. Slow crop growth during winter months provide ample opportunity to the growth of weeds. Maintenance of adequate crop cover turns the competition in favour of crop. Intercropping itself has been found helpful in limiting weed population by way of cutting light to them. So field pea may be introduced between the rows of baby corn. Intercropping of legumes with maize has been found to give yield advantage owing to efficient utilization of growth resources and maintenance of soil health (Singh et al., 1998). Mishra (2014) reported that maize + field pea intercropping system resulted an extra advantage of 85.6 per cent in terms of maize equivalent yield over sole maize. Weed suppression in intercropping through more efficient use of environmental resources by component crops has also been reported by Mashingaizde et al., (2000).

Development of feasible and economically viable intercropping system depends largely on adoption of proper planting pattern as well as weed management. Efficiency of production in intercropping system could be improved by minimizing inter-specific competition between the component crops. Planting pattern alters the space available to individual plant; hence the degree of competition for natural resources becomes variable between component crops. Appropriation of suitable planting pattern is thus, necessary to bring the competition to the minimum level. Chalka and Nepalia (2005) at Navsari, Gujarat indicated that when soybean and cowpea were intercropped with maize in 2:1 row ratio, there was marked reduction in weed density and dry weight compared to sole maize. Weeds are one of the major obstacles that severely affect the productivity and quality of the component crops. Weeds compete with the crop plants for nutrients, moisture and light and thus, reduce the yield considerably. Keeping the above points in view, the experiment was conducted to see the response of weeds, field pea and baby corn to planting pattern and weed management on field pea + baby corn intercropping system.

\section{Materials and Methods}

The experiment was conducted during rabi seasons of 2011-12 and 2012-13 in Dr. Norman E. Borlaug Crop Research Centre, G.B. Pant University of Agriculture and Technology, Pantnagar, Uttarakhand $\left(29^{\circ} \mathrm{N}\right.$, $79.3^{\circ} \mathrm{E}$ and $243.84 \mathrm{~m}$ above mean sea level). 
The maximum temperature during the crop season of 2011-12 and 2012-13 ranged between $17.5-36.5^{\circ} \mathrm{C}$ and $12.0-40.6^{\circ} \mathrm{C}$, respectively. The minimum temperature during the same period ranged between 3.7$21.5^{\circ} \mathrm{C}$ and $2.5-23.7^{\circ} \mathrm{C}$, respectively. A total rainfall of $1.16 \mathrm{~mm}$ and $5.44 \mathrm{~mm}$ were received during the crop season of 2011-12 and 2012-13 respectively. There was frost in the second fortnight of January during 20122013. The soil was sandy loam in texture with high in organic carbon $(0.79 \%)$, low in available nitrogen $\left(210.6 \mathrm{~kg} \mathrm{~N} \mathrm{ha}{ }^{-1}\right)$ and medium in available phosphorus $(16.5 \mathrm{~kg}$ $\left.\mathrm{P} \mathrm{ha}^{-1}\right)$ and potassium contents $(184.7 \mathrm{~kg} \mathrm{~K}$ $\mathrm{ha}^{-1}$ ) and neutral in soil reaction $(\mathrm{pH}$ 7.3). The experiment was laid out in split-plot design with three replications. Main plot consisted of four planting patterns viz. field pea sole (30 $\mathrm{cm})$, baby corn sole $(45 \mathrm{~cm})$, planting of maize + field pea (1:1) and paired planting of maize $(30 / 60 \mathrm{~cm})+$ field pea $(2: 2)$ and sub-plot consisted of four weed management practices $v i z$. weedy check, hand weeding at 30 days after sowing (DAS), pre-emergence (PE) application of pendimethalin $1 \mathrm{~kg} \mathrm{ha}^{-1}$ and post-emergence (POE)application of imazethapyr $50 \mathrm{~g} \mathrm{ha}^{-1}$ at 30 DAS. Maize crop was fertilized with 120,60 and $40 \mathrm{~kg} \mathrm{ha}^{-1}$ of $\mathrm{N}$, $\mathrm{P}_{2} \mathrm{O}_{5}$ and $\mathrm{K}_{2} \mathrm{O}$ through urea, single super phosphate and muriate of potash respectively. Half dose of nitrogen and full dose of $\mathrm{P}_{2} \mathrm{O}_{5}$ and $\mathrm{K}_{2} \mathrm{O}$ were applied as basal in all the plots and remaining dose of $\mathrm{N}$ was applied at knee high stage of the crop as top dressing. A dose of $18 \mathrm{~kg} \mathrm{~N}, 48 \mathrm{~kg} \mathrm{P}_{2} \mathrm{O}_{5}$ and $24 \mathrm{~kg} \mathrm{~K}_{2} \mathrm{O} \mathrm{ha}^{-1}$ was applied to field pea sole through NPK mixture (12:32:16) applied @ $150 \mathrm{~kg} \mathrm{ha}^{-1}$ as basal. No additional dose of fertilizer to pea was given to intercropping system.

The weeds falling within the quadrate $(50 \mathrm{~cm} \times 50 \mathrm{~cm})$ were counted to obtain weed population. For obtaining dry weight of weeds, weeds within the quadrate were removed, sun dried in a hot air oven at $65 \pm 5^{\circ} \mathrm{C}$ till the constant weight. Weed control efficiency (WCE) was calculated based on the dry weight of weeds obtained at 90 DAS i.e. at maximum dry weight stage with the help of following formula:

WCE $=$

Dry matter of weeds - Dry matter of weeds in weedy plot in treated plot

Dry matter of weeds in weedy plot

Nitrogen, phosphorus and potassium content in weeds were estimated from dry matter accumulation at 90 days after sowing. Oven dried weed samples were ground with the help of Willey mill grinder. Total nitrogen, phosphorus and potassium contents were estimated by modified Kjeldahl method, Vanado-molybdo yellow phosphoric spectrophotometric and flame photometric methods respectively (Jackson, 1973). The nutrient uptake by grain and straw of field pea and baby corn for each plot was calculated as follows:

\section{Nutrient uptake $\left(\mathrm{kg} \mathrm{ha}^{-1}\right)$ \\ $=\frac{\text { Nutrient content }(96) \text { XOven dry weight (kg ha }-1)}{100}$}

Picking of baby corn cobs were done three days after silking of the cobs with hand. The fresh weight of baby corn after removing the husk per picking for each net plot was summed up to get total weight of baby corn per plot.

Crop equivalent yield (CEY) was calculated by using the following formula:

$\mathrm{Y}_{1} \mathrm{P}_{1}=\mathrm{Y}_{2} \mathrm{P}_{2}$

where $Y_{1}$ and $Y_{2}$ are the yields of component 1 and 2 respectively and $\mathrm{P}_{1}$ and $\mathrm{P}_{2}$ are the prices of component 1 and 2 respectively. 
The data collected for various parameters were subjected to the analysis by using STPR-1, programme developed by Department of Statistics and Mathematics, College of Basic Science and Humanities, Pantnagar. Comparison of treatment means was done using critical differences (CD) at 5 per cent level of significance.

\section{Results and Discussion}

\section{Total weed density}

Weed flora of experimental field consisted of sedges, grassy and broad leaf weeds. Of the weed species identified, three species were prominent viz. Phalaris minor, Cyperus rotundus and Argemone maxican under weedy check. The total weed population recorded at different stages in weedy check plot revealed that the crop was severely infested with weeds throughout the growth period. The density of weeds increased up to 60 days stage of crop growth and there after started decreasing. The lowest density was observed at 120 days stage in all the treatments (Table 1). The lowest weed density in the later stage was the result of drying of weeds because of intense competition among the weeds during subsequent growing period of crop and decaying of weeds due to termination of their life cycle as weeds usually have shorter life span than crop plants. Both the intercropping systems recorded lower total weed density than the sole cropping of field pea or baby corn during both the years. Lower total weed density observed in intercropping systems than sole planting of field pea or baby corn was due to the fact that intercropping provides an efficient utilization of environmental resources especially the light. Thus, the growth of weeds, depending on the availability of environmental resources was decreased. Weed suppression in intercropping through more efficient use of environmental resources by component crops has also been reported by Poggio (2005). Sole and intercropped field pea reduced the population and dry weight of weeds more than that of baby corn sole due to its smothering effect. Kurchania et al., (1995), Dubey (1998) and Sanjay et al., (2011) also reported similar findings. Hand weeding (30 DAS) recorded the lowest total weed density which was followed by PE application of pendimethalin 1 $\mathrm{kg} \mathrm{ha}^{-1}$, POE application of imazethapyr 50 gha $^{-1}$ (30 DAS) and weedy check. Variation in the density of weeds in different weed control treatments was due to varying effect of herbicides and hand weeding on number of weeds per unit area. These results are in line with those obtained by Khan et al., (2002), Muhammad and Hassan (2003) and Fathiet al., (2003); they reported the highest weed density in weedy check plots and the lowest with chemical weed control. The interaction between planting patterns and weed management practices at 90 DAS was significant during both the years with respect to total weed density (Table 2). Both the intercropping systems recorded lower total weed density than sole planting of field pea and baby corn under all weed management practices during both the years. The lowest total weed density was observed in hand weeding at 30 DAS which was followed by PE application of pendimethalin $1 \mathrm{~kg} \mathrm{ha}^{-1}$, POE application of imazethapyr $50 \mathrm{~g} \mathrm{ha}^{-1}$ at 30 DAS and weedy check under all the planting patterns.

\section{Total dry matter of weeds}

The maximum dry matter production of the weeds occurred at 90 days stage, although the highest weed population was observed at 60 days stage (Table 3). This indicated that maximum flush of weeds emerged with the emergence of crop and increased the dry matter accumulation by individual weed with the advancement of crop growth. Both the intercropping systems showed lower weed dry 
weight than sole field pea and baby corn. The lower weed dry weight in case of intercropping than that of sole planting was the result of reduction in total weed density in intercropping systems and its reduced growth as a result of more photosynthetically active radiation (PAR) interception and also greater water and nutrients extraction by intercrops. Katsaruware and Manyanhaire (2009) concluded that maize + cowpea intercropping reduced weed biomass when compared to sole crops which was as a result of limited availability of resources to weed species, where incoming PAR reaching the ground was reduced by maize + cowpea intercrops. Higher weed dry weight in baby corn sole $(45 \mathrm{~cm})$ than field pea sole $(30 \mathrm{~cm})$ was also due to higher weed density in sole baby corn. These results are in accordance with those of Sanjay et al., (2011) who reported the highest weed dry matter production under sole maize which was higher than sole blackgram and intercropping systems. Weedy check plots had significantly higher dry weight of weeds than hand weeded and herbicide treated plots. The maximum dry weight of weeds in weedy check plots was due to more number of weeds and their growth. Decrease in dry weight of weeds in different weed control treatments was due to varying degree of weed suppressing ability of management practices. These results corroborate the findings of Devender et al., (1998) and Saini (2000) who reported that dry weights of all weed species were significantly reduced under hand weeding and chemical weed control treatments.

\section{Weed control efficiency}

Paired planting of maize $(30 / 60 \mathrm{~cm})+$ field pea $(2: 2)$ being at par with planting of maize + field pea $(1: 1)$ had significantly higher weed control efficiency than field pea sole $(30 \mathrm{~cm})$ and baby corn sole $(45 \mathrm{~cm})$ planting during 2011-12. During 2012-13, paired planting of maize $(30 / 60 \mathrm{~cm})+$ field pea $(2: 2)$ computed significantly higher weed control efficiency than remaining planting pattern treatments (Table 4). Higher weed control efficiency (WCE) in intercropping systems as compared to sole cropping was due to better suppression of weeds by intercropping systems as evidenced by reduced weed density and dry matter accumulation as a result of better utilization of resources by the component crops. Among the weed management practices, hand weeding (30 DAS) had statistically similar weed control efficiency as PE application of pendimethalin $1 \mathrm{~kg} \mathrm{ha}^{-1}$, both these treatments had significantly higher weed control efficiency than POE application of imazethapyr $50 \mathrm{~g} \mathrm{ha}^{-1}$ (30 DAS) during both the years. Comparatively higher weed control efficiency observed in hand weeded and herbicide treated plots than weedy check treatment could be attributed to the lower density as well as dry matter accumulation by weeds in these treatments. Lower weed control efficiency among the herbicides was associated with POE application of imazethapyr $50 \mathrm{~g} \mathrm{ha}^{-1}$ (30 DAS). It might be due to higher weed intensity and dry matter accumulation of weeds in this treatment. These results corroborate with the findings of Saini and Angiras (1998) and Sreenivas and Satyanarayana (1994).

\section{Nutrient (N, P and $K$ ) content and their uptake by weeds}

Planting patterns and weed management practices had no significant effect on nitrogen, phosphorus and potassium content of weeds during both the years (Table 5). Uptake of nutrients ( $\mathrm{N}, \mathrm{P}$ and $\mathrm{K}$ ) by weeds found in sole baby corn or field pea sole was higher than that in both the intercropping systems although the differences were non-significant (Table 6). Higher accumulation of weed dry matter in sole planting resulted in more nutrient removal by weeds as total nutrient 
uptake by weeds is a function of total dry matter and nutrient concentration present in the weeds. The results agreed with the findings of Sanjay et al., (2011) who reported maximum nitrogen removal by weeds in sole maize than under sole blackgram as well as intercropping systems. Weeds of the weedy check plot had significantly higher nutrient uptake $(\mathrm{N}, \mathrm{P}$ and $\mathrm{K})$ than that of the hand weeded and herbicide treated plots. The reason for higher nutrient uptake in weedy check plots was due to higher dry matter accumulation by the weeds under this treatment.

\section{Grain yield of field pea per hectare}

During 2011-12, sole planting of field pea (30 $\mathrm{cm})$ produced the highest grain yield $(2264 \mathrm{~kg}$ $\mathrm{ha}^{-1}$ ) which was followed by paired planting of maize $(30 / 60 \mathrm{~cm})+$ field pea $(2: 2)(1528 \mathrm{~kg}$ $\left.\mathrm{ha}^{-1}\right)$ and planting of maize + field pea $(1: 1)$ (1108 kg ha ${ }^{-1}$ ) (Table 7). All these treatments differed significantly from one another.

During 2012-13, field pea sole $(30 \mathrm{~cm})$ produced significantly higher grain yield $\left(1435 \mathrm{~kg} \mathrm{ha}^{-1}\right)$ than planting of maize + field pea $(1: 1)\left(888 \mathrm{~kg} \mathrm{ha}^{-1}\right)$ and paired planting of maize $(30 / 60 \mathrm{~cm})+$ field pea $(2: 2)(764 \mathrm{~kg}$ $\left.\mathrm{ha}^{-1}\right)$. The difference between planting of maize + field pea $(1: 1)$ and paired planting of maize $(30 / 60 \mathrm{~cm})+$ field pea $(2: 2)$ was nonsignificant. On an average, sole planting of field pea yielded 85.3 and 61.4 per cent more grain yield over planting of maize + field pea $(1: 1)$ and paired planting of maize $(30 / 60 \mathrm{~cm})$ + field pea (2:2) respectively. Higher yield of field pea in the treatments where it was grown alone might be due to higher planting density, plant height and higher values of yield attributing characters like number of pods per plant, grains per pod and grain yield per plant. The lower grain yield of field pea grown in association with baby corn was probably the result of inter-specific competition between corn and field pea plants for below and above ground growth factors i.e. soil moisture, nutrient, space and solar radiation. Also lower grain yield in intercropped plots may be due to shading effect of baby corn on field pea due to variation in plant architecture and aggressive effect of $\mathrm{C}_{4}$ plant (baby corn) on $\mathrm{C}_{3}$ plant (field pea). The results of present investigation are in conformity with those of Carruthers et al., (2000), Banik et al., (2006) and Das et al., (2013) who reported the highest grain yield of soybean under sole planting which was statistically different from those obtained from maize + soybean at single row and maize + soybean at paired row arrangement. Reduction in the grain yield of urdbean (Upasani et al., 2000) and common bean (Maingi et al., 2000) when intercropped with maize has also been reported. Hand weeding (30 DAS) recorded significantly higher grain yield than remaining weed management practices during both the years. The difference in grain yield obtained from PE application of pendimethalin $1 \mathrm{~kg}$ $\mathrm{ha}^{-1}$ POE application of imazethapyr $50 \mathrm{~g} \mathrm{ha}^{-1}$ (30 DAS) was non-significant. Both these treatments had significantly higher grain yield than weedy check. On an average, hand weeding (30 DAS), PE application of pendimethalin $1 \mathrm{~kg} \mathrm{ha}^{-1}$ and POE application of imazethapyr $50 \mathrm{~g} \mathrm{ha}^{-1}$ (30 DAS) yielded $50.8,31.6$ and 24.0 per cent higher yield over weedy check respectively. The higher grain yield in these treatments could be attributed to improve yield components such as more number of pods per plant, number of grains per pod, grain yield per plant etc. The improvement in yield components was in turn due to improved growth attributes such as higher total dry matter production and higher crop growth rate and relative growth rate, more nodules per plant etc. 
Table.1 Effect of planting patterns and weed management practices on total weed density (plants/m²) during 2011-12 and 2012-13

\begin{tabular}{|c|c|c|c|c|c|c|c|c|}
\hline \multirow[t]{3}{*}{ Treatment } & \multicolumn{8}{|c|}{ Total weed density (plants $/ \mathrm{m}^{2}$ ) } \\
\hline & \multicolumn{2}{|c|}{30 DAS } & \multicolumn{2}{|c|}{60 DAS } & \multicolumn{2}{|c|}{90 DAS } & \multicolumn{2}{|c|}{120 DAS } \\
\hline & 2011-12 & 2012-13 & 2011-12 & 2012-13 & 2011-12 & 2012-13 & 2011-12 & 2012-13 \\
\hline \multicolumn{9}{|l|}{ Planting pattern } \\
\hline Field pea sole $(30 \mathrm{~cm})$ & $5.24(203.7)$ & $5.19(190.4)$ & $4.82(141.1)$ & $4.86(145.9)$ & 4.64(115.2) & $4.65(116.3)$ & $4.09(65.3)$ & $4.02(61.2)$ \\
\hline Baby corn sole $(45 \mathrm{~cm})$ & $5.12(176.4)$ & $5.23(198.1)$ & $5.24(207.0)$ & $5.35(229.9)$ & $4.87(145.6)$ & $4.95(154.1)$ & $4.18(71.1)$ & $3.90(53.9)$ \\
\hline Planting of maize + field pea $(1: 1)$ & $5.21(193.9)$ & $5.17(185.1)$ & $4.77(133.2)$ & $4.80(136.7)$ & $4.59(108.8)$ & $4.59(109.1)$ & $3.98(57.1)$ & $3.93(53.7)$ \\
\hline $\begin{array}{l}\text { Paired planting of maize }(30 / 60 \mathrm{~cm})+\text { field } \\
\text { pea }(2: 2)\end{array}$ & $5.12(178.0)$ & $5.06(165.4)$ & $4.72(125.0)$ & $4.76(131.9)$ & $4.47(95.9)$ & $4.45(94.9)$ & $3.84(49.7)$ & $3.78(46.4)$ \\
\hline S.Em. \pm & $0.04(7.91)$ & $0.03(6.7)$ & $0.03(8.5)$ & $0.03(6.4)$ & $0.04(6.2)$ & $0.07(11.5)$ & $0.04(2.5)$ & $0.06(4.3)$ \\
\hline CD at $5 \%$ & NS & NS & $0.13(29.5)$ & $0.13(22.0)$ & $0.15(21.6)$ & $0.25(39.6)$ & $0.17(8.6)$ & NS \\
\hline \multicolumn{9}{|l|}{ Weed management } \\
\hline Weedy & $5.34(209.9)$ & $5.32(206.3)$ & $5.54(260.0)$ & $5.60(276.1)$ & $5.27(197.8)$ & $5.27(198.0)$ & $4.56(97.6)$ & $4.45(87.7)$ \\
\hline Hand weeding (30 DAS) & $5.42(229.2)$ & $5.42(228.4)$ & $4.45(86.8)$ & 4.47(89.6) & $4.19(66.5)$ & $4.20(67.3)$ & $3.65(38.0)$ & $3.44(30.6)$ \\
\hline Pendimethalin $1 \mathrm{~kg} \mathrm{ha}^{-1}$ (PE) & $4.59(98.6)$ & $4.63(103.2)$ & $4.83(127.4)$ & $4.87(133.5)$ & $4.51(92.4)$ & $4.55(96.4)$ & $3.85(47.5)$ & $3.77(43.5)$ \\
\hline Imazethapyr $50 \mathrm{~g} \mathrm{ha}^{-1}$ (POE, 30 DAS) & $5.36(214.2)$ & $5.29(201.1)$ & $4.74(132.1)$ & $4.82(145.1)$ & $4.60(108.8)$ & $4.62(112.8)$ & $4.05(60.1)$ & $3.96(53.5)$ \\
\hline S.Em. \pm & $0.02(4.6)$ & $0.03(7.1)$ & $0.03(6.8)$ & $0.03(8.3)$ & $0.03(6.7)$ & $0.05(7.5)$ & $0.03(3.0)$ & $0.04(3.0)$ \\
\hline CD at $5 \%$ & 0.07(13.6) & $0.10(20.7)$ & 0.11(19.8) & $0.10(24.3)$ & $0.11(19.5)$ & $0.16(21.9)$ & $0.10(8.6)$ & $0.12(8.9)$ \\
\hline
\end{tabular}

*original values are in parentheses and values outside the parenthesis are log $(x+1)$ transformed; DAS: days after sowing; PE: pre emergence; POE: post emergence 
Table.2 Interaction between planting pattern and weed management on total weed density at 90 day during 2011-12 and 2012-13

\begin{tabular}{|c|c|c|c|c|c|c|c|c|}
\hline \multirow[t]{3}{*}{ Planting pattern } & \multicolumn{8}{|c|}{ Total weed density } \\
\hline & \multicolumn{4}{|c|}{ 2011-12 } & \multicolumn{4}{|c|}{ 2012-13 } \\
\hline & Weedy & $\begin{array}{c}\text { Hand } \\
\text { weeding } \\
(30 \text { DAS })\end{array}$ & $\begin{array}{c}\text { Pendimethalin } \\
1 \text { kg ha }^{-1} \text { (PE) }\end{array}$ & $\begin{array}{l}\text { Imazethapyr } \\
50 \mathrm{~g} \mathrm{ha}^{-1} \text { (POE, } \\
\text { 30 DAS) }\end{array}$ & Weedy & $\begin{array}{c}\text { Hand } \\
\text { weeding } \\
(30 \text { DAS })\end{array}$ & $\begin{array}{l}\text { Pendimethalin } \\
1 \text { kg ha }^{-1}(\mathrm{PE})\end{array}$ & $\begin{array}{l}\text { Imazethapyr } \\
50 \mathrm{~g} \mathrm{ha}^{-1}(\text { POE, } \\
\mathbf{3 0} \text { DAS) }\end{array}$ \\
\hline Field pea sole $(30 \mathrm{~cm})$ & $\begin{array}{c}5.31 \\
(207.2)\end{array}$ & $\begin{array}{c}4.27 \\
(73.2)\end{array}$ & $\begin{array}{c}4.58 \\
(97.6)\end{array}$ & $\begin{array}{c}4.40 \\
(82.8)\end{array}$ & $\begin{array}{c}5.33 \\
(210.7)\end{array}$ & $\begin{array}{c}4.23 \\
(69.0)\end{array}$ & $\begin{array}{c}4.61 \\
(101.1)\end{array}$ & $\begin{array}{c}4.44 \\
(84.4)\end{array}$ \\
\hline $\begin{array}{c}\text { Baby corn sole }(45 \\
\mathrm{cm})\end{array}$ & $\begin{array}{c}5.33 \\
(211.0)\end{array}$ & $\begin{array}{c}4.27 \\
(71.4)\end{array}$ & $\begin{array}{c}4.64 \\
(105.5)\end{array}$ & $\begin{array}{c}5.25 \\
(194.3)\end{array}$ & $\begin{array}{c}5.37 \\
(218.7)\end{array}$ & $\begin{array}{c}4.43 \\
(83.9)\end{array}$ & $\begin{array}{c}4.72 \\
(114.5)\end{array}$ & $\begin{array}{c}5.27 \\
(199.3)\end{array}$ \\
\hline $\begin{array}{c}\text { Planting of maize + } \\
\text { field pea }(1: 1)\end{array}$ & $\begin{array}{c}5.29 \\
(198.8)\end{array}$ & $\begin{array}{c}4.19 \\
(65.6)\end{array}$ & $\begin{array}{c}4.48 \\
(90.8)\end{array}$ & $\begin{array}{c}4.39 \\
(80.0)\end{array}$ & $\begin{array}{c}5.24 \\
(193.9)\end{array}$ & $\begin{array}{c}4.16 \\
(63.9)\end{array}$ & $\begin{array}{c}4.55 \\
(94.2)\end{array}$ & $\begin{array}{c}4.41 \\
(84.4)\end{array}$ \\
\hline \multirow[t]{2}{*}{$\begin{array}{l}\text { Paired planting of } \\
\text { maize }(30 / 60 \mathrm{~cm})+ \\
\text { field pea }(2: 2)\end{array}$} & $\begin{array}{c}5.16 \\
(174.0)\end{array}$ & $\begin{array}{c}4.04 \\
(56.0)\end{array}$ & $\begin{array}{c}4.33 \\
(75.6)\end{array}$ & $\begin{array}{c}4.36 \\
(78.0)\end{array}$ & $\begin{array}{c}5.13 \\
(168.6)\end{array}$ & $\begin{array}{c}3.97 \\
(52.4)\end{array}$ & $\begin{array}{c}4.31 \\
(75.9)\end{array}$ & $\begin{array}{c}4.38 \\
(82.9)\end{array}$ \\
\hline & & \multicolumn{2}{|c|}{ S.Em. \pm} & CD at $5 \%$ & \multicolumn{2}{|c|}{ S.Em. \pm} & \multicolumn{2}{|c|}{ CD at $5 \%$} \\
\hline \multicolumn{2}{|c|}{$\begin{array}{l}\text { Comparison between two planting } \\
\text { patterns at same weed management }\end{array}$} & \multicolumn{2}{|c|}{$\begin{array}{c}0.08 \\
(13.3)\end{array}$} & $\begin{array}{c}0.23 \\
(38.9)\end{array}$ & \multicolumn{2}{|c|}{$\begin{array}{c}0.11 \\
(14.9)\end{array}$} & \multicolumn{2}{|c|}{$\begin{array}{c}0.32 \\
(43.8)\end{array}$} \\
\hline \multicolumn{2}{|c|}{$\begin{array}{c}\text { Comparison between two weed } \\
\text { managements at same planting } \\
\text { pattern }\end{array}$} & \multicolumn{2}{|c|}{$\begin{array}{c}0.08 \\
(13.1)\end{array}$} & $\begin{array}{c}0.25 \\
(39.9)\end{array}$ & \multicolumn{2}{|c|}{$\begin{array}{c}0.12 \\
(17.3)\end{array}$} & \multicolumn{2}{|c|}{$\begin{array}{c}0.38 \\
(54.6)\end{array}$} \\
\hline
\end{tabular}


Table.3 Effect of planting patterns and weed management practices on dry weight of weeds during 2011-12 and 2012-13

\begin{tabular}{|c|c|c|c|c|c|c|c|c|}
\hline \multirow[t]{3}{*}{ Treatment } & \multicolumn{8}{|c|}{ Weed dry weight $\left(\mathrm{g} \mathrm{m}^{-2}\right)$} \\
\hline & \multicolumn{2}{|c|}{30 DAS } & \multicolumn{2}{|c|}{60 DAS } & \multicolumn{2}{|c|}{90 DAS } & \multicolumn{2}{|c|}{120 DAS } \\
\hline & 2011-12 & 2012-13 & 2011-12 & 2012-13 & 2011-12 & 2012-13 & 2011-12 & 2012-13 \\
\hline \multicolumn{9}{|l|}{ Planting pattern } \\
\hline Field pea sole $(30 \mathrm{~cm})$ & 26.5 & 27.7 & 88.5 & 92.9 & 156.9 & 158.0 & 130.0 & 133.7 \\
\hline Baby corn sole $(45 \mathrm{~cm})$ & 28.3 & 28.2 & 99.1 & 104.1 & 158.8 & 159.9 & 118.6 & 121.9 \\
\hline Planting of maize + field pea $(1: 1)$ & 28.3 & 26.1 & 83.0 & 87.2 & 143.4 & 145.3 & 125.0 & 129.5 \\
\hline $\begin{array}{c}\text { Paired planting of maize }(30 / 60 \mathrm{~cm})+ \\
\text { field pea }(2: 2)\end{array}$ & 26.0 & 26.3 & 79.1 & 83.1 & 125.7 & 128.9 & 111.1 & 113.6 \\
\hline S.Em. \pm & 0.9 & 1.4 & 3.3 & 3.4 & 9.9 & 8.4 & 5.0 & 9.9 \\
\hline CD at $5 \%$ & NS & NS & 11.5 & 11.6 & NS & NS & NS & NS \\
\hline \multicolumn{9}{|l|}{ Weed management } \\
\hline Weedy & 30.9 & 31.4 & 152.8 & 160.4 & 227.3 & 231.6 & 194.9 & 201.7 \\
\hline Hand weeding (30 DAS) & 30.4 & 29.8 & 58.8 & 61.7 & 99.4 & 99.7 & 84.1 & 85.7 \\
\hline Pendimethalin $1 \mathrm{~kg} \mathrm{ha}^{-1}$ (PE) & 17.1 & 15.2 & 66.5 & 69.8 & 99.9 & 98.9 & 88.4 & 90.1 \\
\hline Imazethapyr $50 \mathrm{~g} \mathrm{ha}^{-1}$ (POE, 30 DAS) & 30.7 & 31.9 & 71.7 & 75.3 & 158.1 & 162.0 & 117.3 & 121.4 \\
\hline S.Em. \pm & 1.3 & 1.5 & 5.0 & 6.1 & 6.8 & 7.3 & 8.5 & 7.9 \\
\hline CD at $5 \%$ & 3.7 & 4.3 & 14.7 & 17.9 & 19.9 & 21.3 & 24.8 & 23.1 \\
\hline
\end{tabular}

DAS: days after sowing; PE: pre emergence; POE: post emergence 
Table.4 Effect of planting patterns and weed management practices on weed control efficiency (WCE) during 2011-12 and 2012-13

\begin{tabular}{|c|c|c|}
\hline \multirow[t]{2}{*}{ Treatment } & \multicolumn{2}{|c|}{ Weed control efficiency $(\%)$} \\
\hline & 2011-12 & 2012-13 \\
\hline \multicolumn{3}{|l|}{ Planting pattern } \\
\hline Field pea sole $(30 \mathrm{~cm})$ & 44.33 & 43.16 \\
\hline Baby corn sole $(45 \mathrm{~cm})$ & 44.08 & 42.16 \\
\hline Planting of maize + field pea $(1: 1)$ & 47.51 & 49.43 \\
\hline Paired planting of maize $(30 / 60 \mathrm{~cm})+$ field pea $(2: 2)$ & 52.77 & 56.40 \\
\hline S.Em. \pm & 1.55 & 1.72 \\
\hline CD at $5 \%$ & 5.38 & 5.96 \\
\hline \multicolumn{3}{|l|}{ Weed management } \\
\hline Weedy & - & - \\
\hline Hand weeding (30 DAS) & 56.07 & 56.52 \\
\hline Pendimethalin $1 \mathrm{~kg} \mathrm{ha}^{-1}$ (PE) & 55.37 & 56.49 \\
\hline Imazethapyr $50 \mathrm{~g} \mathrm{ha}^{-1}$ (POE, 30 DAS) & 30.08 & 30.36 \\
\hline S.Em. \pm & 0.93 & 1.10 \\
\hline CD at $5 \%$ & 2.81 & 3.31 \\
\hline
\end{tabular}

DAS: days after sowing; PE: pre emergence; POE: post emergence

Table.5 Effect of planting patterns and weed management practices on nutrient content of weeds during 2011-12 and 2012-13

\begin{tabular}{|c|c|c|c|c|c|c|}
\hline \multirow[t]{3}{*}{ Treatment } & \multicolumn{6}{|c|}{ Nutrient content (\%) } \\
\hline & \multicolumn{2}{|c|}{ Nitrogen } & \multicolumn{2}{|c|}{ Phosphorus } & \multicolumn{2}{|c|}{ Potassium } \\
\hline & $\begin{array}{c}2011- \\
12\end{array}$ & 2012-13 & 2011-12 & 2012-13 & 2011-12 & 2012-13 \\
\hline \multicolumn{7}{|l|}{ Planting pattern } \\
\hline Field pea sole $(30 \mathrm{~cm})$ & 2.06 & 2.09 & 0.36 & 0.36 & 2.29 & 2.32 \\
\hline Baby corn sole $(45 \mathrm{~cm})$ & 2.08 & 2.10 & 0.38 & 0.38 & 2.31 & 2.33 \\
\hline $\begin{array}{c}\text { Planting of maize }+ \text { field pea } \\
(1: 1)\end{array}$ & 2.07 & 2.09 & 0.36 & 0.37 & 2.30 & 2.33 \\
\hline $\begin{array}{l}\text { Paired planting of maize } \\
(30 / 60 \mathrm{~cm})+\text { field pea }(2: 2)\end{array}$ & 2.06 & 2.08 & 0.37 & 0.37 & 2.29 & 2.32 \\
\hline S.Em. \pm & 0.09 & 0.04 & 0.03 & 0.03 & 0.05 & 0.05 \\
\hline CD at $5 \%$ & NS & NS & NS & NS & NS & NS \\
\hline \multicolumn{7}{|l|}{ Weed management } \\
\hline Weedy & 2.07 & 2.10 & 0.37 & 0.38 & 2.30 & 2.33 \\
\hline Hand weeding (30 DAS) & 2.07 & 2.10 & 0.38 & 0.38 & 2.31 & 2.33 \\
\hline Pendimethalin $1 \mathrm{~kg} \mathrm{ha}^{-1}$ (PE) & 2.07 & 2.09 & 0.36 & 0.36 & 2.29 & 2.32 \\
\hline $\begin{array}{c}\text { Imazethapyr } 50 \mathrm{~g} \mathrm{ha}^{-1} \text { (POE, } \\
\text { 30 DAS) }\end{array}$ & 2.05 & 2.07 & 0.35 & 0.36 & 2.29 & 2.32 \\
\hline S.Em. \pm & 0.04 & 0.02 & 0.007 & 0.01 & 0.01 & 0.01 \\
\hline CD at $5 \%$ & NS & NS & NS & NS & NS & NS \\
\hline
\end{tabular}

DAS: days after sowing; PE: pre emergence; POE: post emergence 
Table.6 Effect of planting patterns and weed management practices on nutrient uptake $\left(\mathrm{kg} \mathrm{ha}^{-1}\right)$ by weeds during 2011-12 and 2012-13

\begin{tabular}{|c|c|c|c|c|c|c|}
\hline \multirow[t]{3}{*}{ Treatment } & \multicolumn{6}{|c|}{ Uptake (kg ha $\left.{ }^{-1}\right)$} \\
\hline & \multicolumn{2}{|c|}{ Nitrogen } & \multicolumn{2}{|c|}{ Phosphorus } & \multicolumn{2}{|c|}{ Potassium } \\
\hline & 2011-12 & 2012-13 & 2011-12 & 2012-13 & 2011-12 & 2012-13 \\
\hline \multicolumn{7}{|l|}{ Planting pattern } \\
\hline Field pea sole $(30 \mathrm{~cm})$ & 32.56 & 33.12 & 5.75 & 5.77 & 36.26 & 36.69 \\
\hline Baby corn sole $(45 \mathrm{~cm})$ & 33.14 & 33.61 & 5.94 & 6.15 & 36.72 & 37.39 \\
\hline $\begin{array}{c}\text { Planting of maize }+ \text { field } \\
\text { pea }(1: 1)\end{array}$ & 29.90 & 30.43 & 5.26 & 5.39 & 33.03 & 33.94 \\
\hline $\begin{array}{l}\text { Paired planting of maize } \\
(30 / 60 \mathrm{~cm})+\text { field pea }(2: 2)\end{array}$ & 25.68 & 26.79 & 4.63 & 4.79 & 28.88 & 29.90 \\
\hline S.Em. \pm & 2.21 & 1.79 & 0.41 & 0.37 & 2.67 & 2.22 \\
\hline CD at $5 \%$ & NS & NS & NS & NS & NS & NS \\
\hline \multicolumn{7}{|l|}{ Weed management } \\
\hline Weedy & 47.26 & 48.68 & 8.61 & 8.87 & 52.67 & 54.14 \\
\hline Hand weeding (30 DAS) & 20.74 & 20.95 & 3.74 & 3.79 & 22.94 & 23.26 \\
\hline $\begin{array}{l}\text { Pendimethalin } 1 \mathrm{~kg} \mathrm{ha}^{-1} \\
\text { (PE) }\end{array}$ & 20.79 & 20.66 & 3.61 & 3.60 & 22.94 & 22.90 \\
\hline $\begin{array}{c}\text { Imazethapyr } 50 \mathrm{~g} \mathrm{ha}^{-1} \\
\text { (POE, } 30 \text { DAS) }\end{array}$ & 32.48 & 33.66 & 5.64 & 5.84 & 36.34 & 37.63 \\
\hline S.Em. \pm & 1.48 & 1.70 & 0.35 & 0.40 & 1.76 & 1.79 \\
\hline CD at $5 \%$ & 10.66 & 10.54 & 2.25 & 2.37 & 12.79 & 11.83 \\
\hline
\end{tabular}

DAS: days after sowing; PE: pre emergence; POE: post emergence 
Table.7 Effect of planting patterns and weed management practices on grain and straw yields of field pea and baby corn and stover yield of baby corn during 2011-12 and 2012-13

\begin{tabular}{|c|c|c|c|c|c|c|c|c|c|c|}
\hline \multirow[t]{3}{*}{ Treatment } & \multicolumn{4}{|c|}{ Field pea yield $\left(\mathrm{kg} \mathrm{ha}^{-1}\right)$} & \multicolumn{4}{|c|}{ Baby corn $\left(\mathrm{kg} \mathrm{ha}^{-1}\right)$} & \multicolumn{2}{|c|}{$\begin{array}{l}\text { Field pea grain } \\
\text { equivalent yield }\end{array}$} \\
\hline & \multicolumn{2}{|c|}{ Grain } & \multicolumn{2}{|c|}{ Straw } & \multicolumn{2}{|c|}{ Baby corn } & \multicolumn{2}{|c|}{ Stover } & \multirow[t]{2}{*}{ 2011-12 } & \multirow[t]{2}{*}{ 2012-13 } \\
\hline & 2011-12 & 2012-13 & $\begin{array}{c}2011- \\
12\end{array}$ & $\begin{array}{l}2012- \\
13\end{array}$ & $\begin{array}{l}\text { 2011- } \\
12\end{array}$ & 2012-13 & $\begin{array}{l}2011- \\
12\end{array}$ & $\begin{array}{c}2012- \\
13\end{array}$ & & \\
\hline \multicolumn{11}{|l|}{ Planting pattern } \\
\hline Field pea sole $(30 \mathrm{~cm})$ & 2264 & 1434 & 3263 & 2540 & - & - & - & - & 2264 & 1435 \\
\hline Baby corn sole $(45 \mathrm{~cm})$ & - & - & - & - & 812 & 810 & 3576 & 3533 & 1505 & 1398 \\
\hline Planting of maize + field pea $(1: 1)$ & 1108 & 888 & 2885 & 2032 & 792 & 733 & 1615 & 1572 & 2574 & 2154 \\
\hline $\begin{array}{c}\text { Paired planting of maize }(30 / 60 \mathrm{~cm})+ \\
\text { field pea }(2: 2)\end{array}$ & 1528 & 764 & 2592 & 1946 & 807 & 746 & 1823 & 1780 & 3022 & 2052 \\
\hline S.Em. \pm & 58 & 43 & 80 & 62 & 19 & 23 & 35 & 71 & 68 & 46 \\
\hline CD at $5 \%$ & 229 & 168 & 312 & 242 & NS & NS & 136 & 278 & 236 & 159 \\
\hline \multicolumn{11}{|l|}{ Weed management } \\
\hline Weedy & 1268 & 835 & 2754 & 2047 & 684 & 387 & 1968 & 1925 & 1900 & 1128 \\
\hline Hand weeding (30 DAS) & 1947 & 1225 & 3108 & 2298 & 952 & 896 & 2616 & 2573 & 2783 & 2078 \\
\hline Pendimethalin $1 \mathrm{~kg} \mathrm{ha}^{-1}$ (PE) & 1700 & 1068 & 2849 & 2194 & 801 & 990 & 2731 & 2688 & 2387 & 2082 \\
\hline Imazethapyr $50 \mathrm{~g} \mathrm{ha}^{-1}$ (POE, 30 DAS) & 1620 & 987 & 2943 & 2152 & 778 & 780 & 2037 & 1994 & 2295 & 1750 \\
\hline S.Em. \pm & 38 & 36 & 62 & 34 & 23 & 8 & 69 & 44 & 41 & 40 \\
\hline CD at $5 \%$ & 113 & 106 & 184 & 102 & 69 & 25 & 206 & 130 & 122 & 117 \\
\hline
\end{tabular}

DAS: days after sowing; PE: pre emergence; POE: post emergence 
Thus, the improvement in growth and yield components was as a consequence of lower crop-weed competition, which shifted the balance in favor of crop in the utilization of nutrients, moisture, light and space. Mundra et al., (2003) found that the pre emergence application of atrazine at $0.5 \mathrm{~kg} \mathrm{ha}{ }^{-1}+$ intercultivation at 35 DAS tended to increase mean grain yield by 92.8 per cent over weedy check. The increased yield during 2011-12 than in 2012-13 growing season could be attributed to the greater competitive ability of field pea during that growing season as a result of the favorable weather condition. During 2012-13, there was frost in the month of January-February thereby extending the cold period which resulted yield reduction.

\section{Straw yield of field pea per hectare}

Sole planting of field pea $(30 \mathrm{~cm})$ produced significantly higher straw yield than planting of maize + field pea $(1: 1)$ and paired planting of maize $(30 / 60 \mathrm{~cm})+$ field pea $(2: 2)$ during both the years (Table 7). The difference between planting of maize + field pea $(1: 1)$ and paired planting of maize $(30 / 60 \mathrm{~cm})+$ field pea (2:2) was non-significant. On an average, increased in straw yield in sole planting of field pea than planting of maize + field pea $(1: 1)$ and paired planting of maize $(30 / 60 \mathrm{~cm})+$ field pea $(2: 2)$ was 18.0 and 27.9 per cent respectively. This was mainly due to higher plant population in sole planting of field pea. Similar results were reported by Mandal et al., (2014a) who reported significantly lower straw yield of intercropped soybean and groundnut than in monocropping. During 2011-12, POE application of imazethapyr $50 \mathrm{~g} \mathrm{ha}^{-1}$ (30 DAS) being at par with PE application of pendimethalin $1 \mathrm{~kg} \mathrm{ha}^{-}$ ${ }^{1}$ produced significantly higher straw yield than weedy check. The difference in straw yield between PE application of pendimethalin $1 \mathrm{~kg}$ $\mathrm{ha}^{-1}$ and weedy check was non-significant. During 2012-13, hand weeding (30 DAS) produced significantly higher straw yield than remaining weed management practices. PE application of pendimethalin $1 \mathrm{~kg} \mathrm{ha}$ ${ }^{1}$ produced statistically similar straw yield as post emergence application of imazethapyr 50 $\mathrm{g} \mathrm{ha}^{-1}$ (30 DAS), both these treatments had significantly higher straw yield than weedy check. On an average, hand weeding (30 DAS), pre emergence application of pendimethalin $1 \mathrm{~kg} \mathrm{ha}^{-1}$ and post emergence application of imazethapyr $50 \mathrm{~g} \mathrm{ha}^{-1}$ (30 DAS) yielded 12.6, 5.0 and 6.1 per cent higher straw yield over weedy check respectively.

\section{Baby corn yield per hectare}

The yield of baby corn under different planting patterns was statistically similar during both the years (Table 7). The results of the present investigation are in accordance with those of Mandal et al., (2014b) who found that maize crop produced the highest grain yield in sole cropping which was statistically at par with intercropping situations like maize + soybean (1:2)and maize + groundnut (2:4). During 2011-12, hand weeding (30DAS) (952 $\left.\mathrm{kg} \mathrm{ha}{ }^{-1}\right)$ produced significantly higher baby corn yield than remaining weed management practices. PE application of pendimethalin $1 \mathrm{~kg} \mathrm{ha}^{-1}(801$ $\mathrm{kg} \mathrm{ha}{ }^{-1}$ ) produced statistically similar baby corn yield as POE application of imazethapyr $50 \mathrm{~g} \mathrm{ha}^{-1}$ (30 DAS) (778 kg ha ${ }^{-1}$, both had significantly higher baby corn yield than weedy (684 kg ha ${ }^{-1}$ ). During 2012-13, the maximum baby corn yield was obtained in PE application of pendimethalin $1 \mathrm{~kg} \mathrm{ha}^{-1}(990 \mathrm{~kg}$ $\mathrm{ha}^{-1}$ ) which was followed by hand weeding (30 DAS) $\left(896 \mathrm{~kg} \mathrm{ha}^{-1}\right)$, POE application of imazethapyr $50 \mathrm{~g} \mathrm{ha}^{-1}$ (30 DAS) $\left(780 \mathrm{~kg} \mathrm{ha}^{-1}\right)$ and weedy check (387 $\left.\mathrm{kg} \mathrm{ha}^{-1}\right)$. All these treatments differed significantly from one another. On an average, hand weeding (30 DAS), PE application of pendimethalin $1 \mathrm{~kg}$ $\mathrm{ha}^{-1}$ and POE application of imazethapyr $50 \mathrm{~g}$ $\mathrm{ha}^{-1}$ (30 DAS) yielded 72.6, 67.2 and 45.5 per 
cent higher baby corn yield over weedy check respectively. The higher baby corn yield in hand weeding (30 DAS) and herbicide treated plots were due to better growth and development of baby corn plants as a result of less competition from weeds for light, water, nutrients, carbon dioxide etc. as a result of better control of weeds as indicated by low weed density and weed dry weight. Presence of weeds reduces the photosynthetic efficiency, dry matter production and distribution to economical parts and there by reduces sink capacity of crop resulting in poor yield. The efficiency of chemicals and other weed control practices in increasing grain yield had also been demonstrated by Dixit (1995), Shinde et al., (2001), Khan et al., (2002) and Khan and Haq (2004).

\section{Stover yield of baby corn per hectare}

The highest stover yield was found in baby corn sole $(45 \mathrm{~cm})$ which was followed by paired planting of maize $(30 / 60 \mathrm{~cm})+$ field pea $(2: 2)$ and planting of maize + field pea (1:1) during 2011-12 (Table 7). All these treatments differed significantly from one another. During 2012 -13, baby corn sole (45 $\mathrm{cm}$ ) had significantly higher stover yield than paired planting of maize $(30 / 60 \mathrm{~cm})+$ field pea (2:2) and planting of maize + field pea $(1: 1)$. The difference between paired planting of maize $(30 / 60 \mathrm{~cm})+$ field pea $(2: 2)$ and planting of maize + field pea $(1: 1)$ was nonsignificant. On an average, sole planting of baby corn yielded 123.1 and 97.3 per cent more stover yield over planting of maize + field pea $(1: 1)$ and paired planting of maize $(30 / 60 \mathrm{~cm})+$ field pea $(2: 2)$ respectively. This was mainly due to better growth and dry matter accumulation in sole planting of baby corn. Similar results were reported by Mandalet al., (2014a) who reported that sole maize produced significantly higher stover yield than all other intercropping treatments with groundnut. Among the weed management practices, PE application of pendimethalin $1 \mathrm{~kg} \mathrm{ha}$ had statistically similar stover yield as hand weeding (30 DAS), both had significantly higher stover yield than POE application of imazethapyr 50 $\mathrm{g} \mathrm{ha}^{-1}$ (30 DAS) and weedy check during both the years. On an average, hand weeding (30 DAS), pre emergence application of pendimethalin $1 \mathrm{~kg} \mathrm{ha}^{-1}$ and post emergence application of imazethapyr $50 \mathrm{~g} \mathrm{ha}^{-1}$ (30 DAS) yielded 33.3, 39.2 and 3.5 per cent higher stover yield over weedy check respectively. More stover yield in weed control treatments than weedy check was due to less weed density and better growth and development of baby corn plants, which resulted in more biomass of baby corn plants. These results are in close agreement with Sinhaet al., (2001), Dixit and Gautam (1996) and Shindeet al., (2001) who found that use of herbicides to control weeds resulted in increased plant height, plant population and stover yield.

\section{Field pea equivalent yield}

The highest field pea equivalent yield was recorded in paired planting of maize $(30 / 60$ $\mathrm{cm})+$ field pea $(2: 2)$ which was followed by planting of maize + field pea $(1: 1)$, field pea sole $(30 \mathrm{~cm})$ and baby corn sole $(45 \mathrm{~cm})$ during 2011-12. All these treatments differed significantly from one another. During 2012 13 , planting of maize + field pea $(1: 1)$ had statistically similar field pea equivalent yield as paired planting of maize $(30 / 60 \mathrm{~cm})+$ field pea (2:2), both had significantly higher field pea equivalent yield than sole planting of field pea $(30 \mathrm{~cm})$ and baby corn $(45 \mathrm{~cm})$. Higher field pea equivalent yield in case of intercropping than that of sole planting was mainly due to additional advantage of intercrops yield and higher economic values of intercrops. Similar results were also obtained by Kheroar and Patra (2014) who obtained higher maize grain equivalent yield in all the cases of intercropping of maize with green 
gram, black gram, soybean, groundnut and red gram than sole maize. Hand weeding (30 DAS) had significantly higher field pea equivalent yield than remaining weed management practices during 2011-12. The difference between PE application of pendimethalin $1 \mathrm{~kg} \mathrm{ha}^{-1}$ and POE application of imazethapyr $50 \mathrm{~g} \mathrm{ha}^{-1}$ (30 DAS) was nonsignificant, both had significantly higher field pea equivalent yield than weedy check. During $2012-13, \quad$ PE application of pendimethalin $1 \mathrm{~kg} \mathrm{ha}{ }^{-1}$ had statistically similar field pea equivalent yield as hand weeding (30 DAS), both recorded significantly higher field pea equivalent yield than POE application of imazethapyr $50 \mathrm{~g} \mathrm{ha}^{-1}$ (30 DAS) and weedy check. POE application of imazethapyr $50 \mathrm{~g} \mathrm{ha}^{-1}$ (30 DAS) computed significantly higher field pea equivalent yield than weedy check. In the light of the two years experimental results, it may be concluded that paired planting of maize $(30 / 60 \mathrm{~cm})+$ field pea $(2: 2)$ has been found more remunerative and efficient in terms of yield advantage (field pea equivalent yield) and weed control than planting of maize + field pea (1:1) and sole planting. Hand weeding at 30 DAS proved more beneficial compared to PE application of pendimethalin $1 \mathrm{~kg} \mathrm{ha}^{-1}$, POE application of imazethapyr $50 \mathrm{~g} \mathrm{ha}^{-1}$ (30 DAS) and weedy check.

\section{Acknowledgements}

We wish to thank Dr. Shiva Dhar, Principal Scientist, Division of Agronomy, Indian Agricultural Research Institute (IARI), New Delhi, for his encouragement, suggestions and help in the completion of this manuscript.

\section{References}

Banik, P., Midya, A., Sarkar, B.K. and Ghose, S.S. 2006. Wheat and chickpea intercropping systems in and additive series experiment: Advantages and weed smothering. European Journal of Agronomy. 24: 325-332.

Barod, N.K., Dhar, S. and Kumar, A. 2012. Effect of nutrient sources and weed control methods on yield and economics of baby corn (Zea mays). Indian Journal of Agronomy. 57(1): 96-99.

Carruthers, K., Prithiviraj, B., Cloutier, D., Martin, R.C. and Smith, D.L. 2000. Intercropping corn with soybean, lupin and forages: yield components responses. European Journal of Agronomy. 12(2), 103-115.

Chalka, M.K. and Nepalia, V. 2005. Production potential and economics of maize intercropped with legumes as influenced by weed control. Indian Journal of Agronomy. 50(2): 119-122.

Das, A.K., Khaliq, Q.A. and Haider, M.L. 2013. Effect of planting configurations on yield and yield components in maize + soybean and maize + bushbean intercropping system. International Journal of Experimental Agriculture. 3(1): 38-45.

Devender, S., Tyagi, R.C., Agarwal, S.K. and Singh D. 1998. Weed control methods in spring maize. Haryana Agric. Uni. Journal of Research. 28(1): 21-25.

Dixit, A. 1995. Economics of weed control methods in winter maize. Agricultural Science Digest. Karnal.15(3): 143-145.

Dixit, A. and Gautam, K.C. 1996. Effect of atrazine on growth and yield of winter maize. Annals of Agricultural Research. 17(2): 121-124.

Dubey, M..P. 1998. Growth, yield and economics of soybean (Glycine max) as influenced by weed control methods and row spacing. Indian Journal of Agronomy. 43(3): 540-545.

Fathi, G., Ebrahimpoor, F. and Siadat, S.A. 2003. Efficiency of single and integrated methods (chemicalmechanical) for weed control in Corn 
SC704 in Ahvaz climatic conditions. Iranian Journal of Agricultural Science. 34(10): 187-197.

Jackson, M. L. 1973. Soil chemical analysis. Prentis Hall of India. Pvt. Lid., New Delhi, p.183.Katsaruware, R.D. and Manyanhaire, I.O. 2009. Maizecowpea intercropping and weed suppression in leaf stripped and detasseled maize in Zimbabwe. Journal of environmental, Agricultural and Food Chemistry. 8(1):1218-1226.

Khan, M. and Haq, N. 2004. Weed control in maize (Zea mays L.) with pre-and post- emergence herbicides. Pakistan Journal of Weed Science Research. 10(1/2): 39-46.

Khan, M.A., Marwat, K.B., Gul, H. and Naeem, K. 2002. Impact of weed management on maize (Zea mays L.) planted at night. Pakistan Journal of Weed Science Research. 8(1-2): 57-62.

Kheroar, S. and Patra, B.C. 2014.Productivity of maize-legume intercropping systems under rainfed situation.African Journal of Agricultural Research.9(20): 1610-1617.

Kurchania, S.P., Tiwari, J.P., Bhalla, C.S. and Paradkar, N.R. 1995. Weed control in soybean based intercropping. The World Weeds. 2(3-4): 155-159.

Maingi, J.M., Shisanya, C.A., Gitonga, N.M. and Hornetz, B. 2000. Nitrogen fixation by common bean (Phaseolus vulgaris $\mathrm{L}$.) in pure and mixed stands in semi arid south east Kenya. European Journal of Agronomy. 14(1): 1-12.

Mandal, M.K., Banerjee, M., Banerjee, H., Alipatra, A. and Malik, G. C. 2014 $\mathrm{a}$. Productivity of maize (Zea mays) based intercropping system during kharif season under red and lateritic. The Bioscan. 9(1): 31-35.

Mandal, M.K., Banerjee, M., Banerjee, H., Pathak, A. and Das, R. 2014 b.
Evaluation of cereal-legume intercropping systems through productivity and Competition ability. Asian Journal of Science and Technology. 5(3): 233-237.

Mashingaizde, A.B., Nyakanda, C., Chivinge, O. A., Washaireni, A.M. and Dube, K. W. 2000. Influence of a maize pumpkin live much on weed dynamics and maize yield. African Plant Protection. 6(1): 57-63.

Mishra A., 2014. Effect of winter maize-based intercropping systems on maize yield, associated weeds and economic efficiency. Comunicata Scientiae. 5(2): 110-117.

Muhammad, K. and Hassan, W. 2003. Effect of S Metolachlor (Dual Gold 960 EC) on weed control and yields in different crops. Sarhad Journal of Agriculture. 19(3): 333-339.

Mundra, S.L., Vyas, A.K. and Maliwal, P.L. 2003. Effect of weed and nutrient management on weed growth and productivity of maize (Zea mays L.). Indian Journal of Weed Science. 35(1/2): 57-61.

Poggio, S.L. 2005. Structure of weed communities occurring in monoculture and intercropping of field pea and barley. Journal of Agricultural Ecosytems and Environment.109:4858.

Rao, M.R. and Willey, R.W. 1983. Effect of genotypes in cereal/ pigeonpea intercropping on alfisols of semi-arid tropics of India. Experimental Agriculture. 19: 67-78.

Saini, J.P. 2000. Efficacy of atrazine as post emergence herbicide for weed control in maize (Zea mays L.) under rain-fed conditions. Indian Journal of Agricultural Science. 70(11): 801-803.

Saini, J.P. and Angiras, N.N., 1998. Efficacy of herbicides alone and in mixtures to control weeds in maize under mid-hill 
conditions of Himachal Pradesh. Indian Journal of Weed Science. 30(1/2): 65-68.

Sanjay, K. Dwivedi, G.K., Shrivastava, A.P., Singh and Kolhe, S.S. 2011. Weed population, nitrogen removal by weeds and crop yield under maize + blackgram intercropping system in Chhattisgarh plains. Indian Journal of Weed Science. 43(3\&4): 203-210.

Shinde, S.H., Kolage, A.K. and Bhilare, R.L. 2001.Effect of weed control on growth and yield of maize. Journal of Maharashtra Agricultural University. 26(2): 212-213.

Singh, M.K., Thakur, R., Verma, U.N., Pal, S.K. and Pasupalak, S. 1998. Productivity and nutrient balance of maize (Zea mays) + blackgram (Phaseolus mungo) intercropping as affected by fertilizer and plant density. Indian Journal of Agronomy. 43(3): 495-500.

Sinha, S.P., Prasad, S.M. and Singh, S.J. 2001. Response of winter maize (Zea mays) to integrated weed management. Indian Journal of Agronomy. 46(3): 485- 488.

Sreenivas, G. and Satyanarayana, V., 1994.Nutrient removal by weeds and maize (Zea mays). Indian Journal of Agronomy. 41(1): 160-162.

Upasani, R.R., Singh, M.K., Thakur, R., Verma, U.N. and Pal, S.K. 2000. Plant density and fertilizer management of blackgram and the productivity of maize + blackgram intercropping systems. Journal of Research (BAU), 12(2): 229-231.

\section{How to cite this article:}

Moirangthem Thoithoi Devi and Singh, V. K. 2019. Effect of Planting Pattern and Weed Management Practices on Weeds and Yields of Field Pea and Baby Corn in Field Pea + Baby Corn Intercropping System. Int.J.Curr.Microbiol.App.Sci. 8(12): 1346-1362. doi: https://doi.org/10.20546/ijcmas.2019.812.163 